\title{
LONG-DISTANCE NATAL DISPERSAL IN TREE SWALLOWS: RECAPTURES OF BIRDS WITH BRITISH COLUMBIA ORIGINS IN ALBERTA
}

Donald J. Stiles ${ }^{1}$, Russell D. Dawson²

${ }^{120}$ Lake Wapta Rise SE, Calgary, AB T2J 2M9; E-mail:<stilesdj@shaw.ca>

${ }^{2}$ Ecosystem Science and Management Program, University of Northern British Columbia, 3333 University Way, Prince George, BC V2N $4 Z 9$

Documenting the movement of animals from either their natal or breeding site is important for understanding their population biology. ${ }^{1}$ For most species of birds, the usual method for detecting dispersal events is to mark (band) individuals on a defined study area, and document recaptures and recoveries locally; long-distance movements can be detected through recoveries and recaptures reported to the banding programs of the Canadian Wildlife Service's Bird Banding Office and the U.S. Bird Banding Laboratory. ${ }^{2}$ However, encountering previously banded birds is relatively rare. For example, between 1935 and 2002, of the 610,039 tree swallows (Tachycineta bicolor) banded in Canada and the United States, only 4162 $(0.68 \%)$ were ever reported as recovered or recaptured. ${ }^{2}$ In addition, the mean dispersal distances of tree swallows are relatively short, with an average distance of $8.38 \mathrm{~km}$ and $2.44 \mathrm{~km}$ for females and males, respectively. ${ }^{3}$ Given the low probability of recovering or recapturing banded birds, and the fact that the vast majority of dispersal by tree swallows is well under $10 \mathrm{~km},{ }^{2,3}$ documenting longdistance dispersal movements in tree swallows is quite rare. Here we describe several recaptures of tree swallows that dispersed long distances from their natal area.

In both 2010 and 2011, tree swallows banded in the interior of British Columbia were recovered in Alberta. In 2010, swallow no. 2221-27598, which was banded as a nestling by R.D.D. in 2007 west of Prince George, BC, was recovered by D.J.S. $21 \mathrm{~km}$ east of Didsbury, Alberta. This female bird moved $667 \mathrm{~km}$ SE of its banding location (see Fig. 1). In 2011, bird no. 2311-86804, which was banded as a nestling in 2008 by R.D.D. in the Dog Creek area of $\mathrm{BC}$ was recovered by Mike Risely on his nest box trail about $2.4 \mathrm{~km}$ $\mathrm{S}$ of DeWinton, AB. This female moved $586 \mathrm{~km} \mathrm{ESE}$, in a pattern similar to the movement of no. 2221-27598, described above (Fig. 1).

R.D.D. has studied tree swallows and mountain bluebirds (Sialia currucoides), among other species, in central BC since 2001 and in any given year bands between 1000 and 1500 individuals of these species. The main focus of his research program is to study various aspects of reproductive ecology of birds, including mate choice and parasitism. 


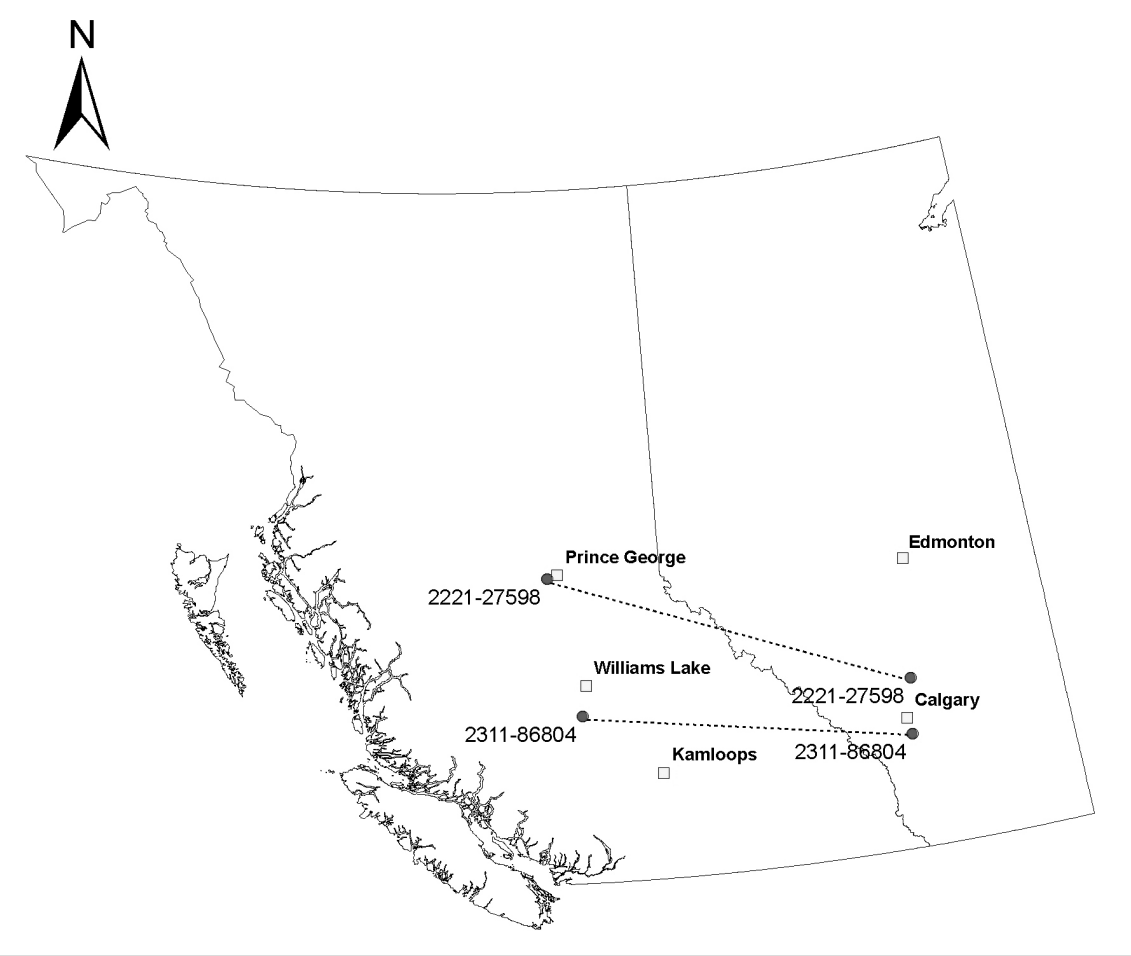

Figure 1. Banding locations of two tree swallows (band nos. 2221-27598 and 2311-86804) in British Columba, and their recapture locations in Alberta.

Tree swallows and mountain bluebirds are used as a study model mainly because they are relatively easy to work on, are accessible because of their use of nest boxes, and are so resilient to investigator disturbance.

The 2010 recovery was banded in a study area approximately $10 \mathrm{~km}$ west of Prince George, BC. That study area has 140 boxes on it, and is one of four areas in the vicinity of Prince George with active research on tree swallows. The 2011 recovery was banded in a study area near the community of Dog Creek, about 85 $\mathrm{km}$ SW of Williams Lake, BC. Unlike the Prince George study areas, which are in the Sub-Boreal Spruce and Pine-Spruce Biogeoclimatic Zones, the Dog Creek study area is along the Fraser River in the arid Interior Douglas-fir Bunchgrass Zone. This study area contains 190 paired boxes, and the main focus of the study is bluebirds. Generally, each pair of boxes has a pair of bluebirds, with tree swallows arriving later in the season and occupying the adjacent empty box.

D.J.S. and M. Risely are members of the Calgary Area Nestbox Monitors (also known as Calgary Area Bluebird Trail Monitors). This is a group of 58 teams who monitor nest box trails from Nanton south of Calgary to Olds and Sundre north of Calgary. In 2011, they monitored 4724 nest boxes, which fledged 13,911 tree swallows and 5053 mountain bluebirds in their first broods 
and 261 bluebirds in second broods. Twenty-four of the monitors are also banders. In the period 2006 to 2010 , they banded an average of 3546 tree swallows and 3262 mountain bluebirds per year. In 2011, they recaptured 217 tree swallows and 186 mountain bluebirds that they and others had previously banded.

\section{Previous Recoveries}

Over the past decade, one adult tree swallow banded in BC by R.D.D. has been recovered in Texas, and one nestling was subsequently captured breeding near a power plant in Ontario. Details follow:

Band no. 3121-31959: This bird was an adult male banded on 17 June 2003, $20 \mathrm{~km}$ SSE of Prince George, $\mathrm{BC}\left(53^{\circ} 45^{\prime} \mathrm{N}, 122^{\circ} 35^{\prime} \mathrm{W}\right)$. This was a breeding bird whose mate laid seven eggs (clutch initiation date 28 May 2003) and hatched six young (hatching date 16 June 2003). The pair successfully fledged five offspring. According to the "Report to Bander", this bird was shot on 26 October 2003 , at Spring Lake, Texas ( $34^{\circ} 13^{\prime} \mathrm{N}$, $\left.102^{\circ} 1^{\prime} \mathrm{W}\right)$, by a resident of Lubbock.

Band no. 2221-27623: This bird hatched on 17 June 2006, $20 \mathrm{~km}$ SSE of Prince George, BC (53 $\left.45^{\prime} \mathrm{N}, 122^{\circ} 35^{\prime} \mathrm{W}\right)$. It was in a nest that had seven eggs, all of which hatched and successfully fledged. It was banded on 3 July 2006 when it was 16 days old. The bird was recaptured on 9 July 2009, near Nanticoke, ON (Ontario Power Generation Plant; $42^{\circ} 48^{\prime} \mathrm{N}, 80^{\circ}$ 04' W) by Linda Thrower of Dunnville, $\mathrm{ON}$. The bird was recovered alive and had three nestlings. It had dispersed approximately $3325 \mathrm{~km}$ from its natal nest in BC. Thrower and her husband operate 100 nestboxes at the Ontario Power Generation Plant on the North Shore of Lake Erie, as part of the plant's environmental program. Thrower reported that this female has not subsequently been recaptured on her study area.

Previous recoveries of tree swallows banded by D.J.S. in Alberta and Mary Houston in Saskatchewan have previously been reported, ${ }^{4,5}$ and are summarized as follows:

Four (two $A B$, two $S K$ ) recovered in Louisiana.

Two AB birds wintered in California (or south of there) - both were captured at a National Wildlife Refuge in northeastern California on spring migration; one was banded there and later recaptured in $A B$, while the second had previously been banded in $A B$ and was recaptured in California.

Two $A B$ birds recovered on migration in South Dakota and Nebraska.

One SK bird recovered in Michigan.

One AB bird recovered in east Texas

\section{Discussion}

Butler $(1988)^{6}$ examined migration routes of tree swallows in North America and concluded that birds breeding in the prairie provinces and American midwest tend to migrate southeast and follow the Mississippi drainage to the Gulf coast, with some birds being recovered along the Atlantic coast (see also Brewer et al. $2000^{7}$ ). Tree swallows breeding along the eastern slopes of the Rocky Mountains are thought to migrate due south to Mexico, ${ }^{6}$ and Brewer et al. (2000) ${ }^{7}$ hypothesized that birds west of the Rockies would follow a similar pattern. In contrast, tree swallows in eastern Canada migrate primarily southwest along the Atlantic coast, mainly to Florida. ${ }^{6}$ Birds in Ontario seem to be intermediate, with some 
birds moving southeast to the Atlantic coast while others take a more south or southwestern direction to the Gulf coast. $^{7}$

The recoveries that we report here, as well as those previously reported, ${ }^{4,5}$ suggest that the migration routes of tree swallows may be more variable than previously thought. Both the 2010 and the 2011 recoveries in Alberta were of tree swallows banded as young in $\mathrm{BC}$ and recaptured at 3 years old. Assuming they migrated successfully twice and returned, and on the third return stopped in Alberta at distances of $667 \mathrm{~km} \mathrm{SE}$ and $586 \mathrm{~km}$ ESE of their original banding location, both birds at some point crossed the Rocky Mountains. Similarly, while most of the recoveries reported previously $y^{4,5}$ support the idea that prairie birds follow the Mississippi drainage south, the two Alberta birds recovered in California also suggest that this is not always the case.

The maximum movement of a tree swallow for any encounter type was reported as $3611 \mathrm{~km}$, with a bird banded as a nestling in 1973 near Barrhead, $A B$, being recovered in Burgess, $S C$, in October of the same year, presumably on its wintering area. ${ }^{7}$ In terms of dispersal from natal sites to future breeding sites, the maximum distance was reported as $2367 \mathrm{~km}$, with a bird banded in 1991 as a nestling in Washington State being recovered in Michigan the following year. ${ }^{2}$ The recapture in Ontario of the tree swallow banded by R.D.D. in BC, with a dispersal distance of approximately $3325 \mathrm{~km}$, therefore represents one of the longest, if not the longest, known distance dispersed by a tree swallow between its natal and breeding locations. A previous study also reported that there are only 13 records of tree swallows dispersing more than $500 \mathrm{~km} .{ }^{2}$ The two BC birds recaptured in Alberta by D.J.S. and M. Risely both exceed $500 \mathrm{~km}$, and so are also relatively unusual in terms of the long distance that they had moved. Regardless, we know little about the factors that determine dispersal distances, or migration routes, even in species such as tree swallows that are well studied; future research and continued banding of these birds will serve to shed additional insight on these issues.

\section{Acknowledgments}

We wish to thank all the individuals that have helped with monitoring nest boxes and banding birds over the years, and Theo Mlynowski for making the map. R.D.D.'s work is funded by the Natural Sciences and Engineering Research Council of Canada and the University of Northern British Columbia.

1. Clobert J, Danchin E, Dhondt AA, Nichols JD (eds) (2001) Dispersal. Oxford University Press, New York, NY.

2. Hosner PA, Winkler DW (2007) Dispersal distances of tree swallows estimated from continent-wide and limited-area data. Journal of Field Ornithology 78:290-297.

3. Winkler DW, Wrege PH, Allen PE, Kast TL, Senesac P, Wasson MF, Sullivan PJ (2005) The natal dispersal of tree swallows in a continuous mainland environment. Journal of Animal Ecology 74:1080-1090.

4. Stiles DJ, Houston MI (2003) More United States tree swallow recoveries. Blue Jay 61:201-203.

5. Stiles DJ (2008) An Alberta banded tree swallow recovered in East Texas. Blue Jay 66:52.

6. Butler RW (1988) Population dynamics and migration routes of tree swallows, Tachycineta bicolor, in North America. Journal of Field Ornithology 59:395-402.

7. Brewer AD, Diamond AW, Woodsworth EJ, Collins BT, Dunn EH (2000) The Atlas of Canadian Bird Banding, 1921-95. Volume 1: Doves, cuckoos and hummingbirds through Passerines. Canadian Wildlife Service Special Publication, Ottawa, ON. 